\title{
Lack of Induction of Suppressor T Cells by Intestinal Epithelial Cells from Patients with Inflammatory Bowel Disease
}

\author{
Lloyd Mayer and David Eisenhardt \\ The Mount Sinai Medical Center, Division of Clinical Immunology, New York 10029
}

\begin{abstract}
The mechanisms underlying the chronic unrelenting inflammatory response seen in inflammatory bowel disease (IBD) are poorly understood. We have recently proposed a novel role for the normal intestinal enterocyte, that of antigen presenting cell. However, in contrast to conventional antigen presenting cells, normal enterocytes appear to selectively activate $\mathbf{C D 8}^{+}$ antigen nonspecific suppressor $\mathbf{T}$ cells. To determine whether failure of this process may be occuring in inflammatory bowel disease, freshly isolated enterocytes from small and large bowel from normal patients, patients with Crohn's disease, ulcerative colitis, and inflammatory (diverticulitis, ischemic colitis, and gold induced colitis) controls were co-cultured with allogeneic $\mathbf{T}$ cells in a modified mixed lymphocyte reaction. In contrast to normal enterocytes, 42/42 Crohn's and 35/38 ulcerative colitis-derived epithelial cells stimulated $\mathrm{CD4}^{+} \mathrm{T}$ cells, whereas $65 / 66$ and 9/9 normal and inflammatory control enterocytes, respectively, stimulated $\mathrm{CD8}^{+} \mathrm{T}$ cells (as previously described), suggesting that the results seen were not just a reflection of underlying inflammation. Furthermore, IBD enterocytes from both histologically involved and uninvolved tissue were similar in their ability to selectively activate $\mathrm{CD4}^{+}$ $T$ cells, speaking for a more global defect in epithelial cells in IBD. Finally, activated T cells from IBD epithelial cell-stimulated mixed lymphocyte cultures displayed potent $T$ helper activity in an antigen nonspecific fashion. Taken together, these data suggest that there may be an intrinsic defect in epithelial cells from patients with IBD, resulting in the inability to normally stimulate suppressor $T$ cells in an antigen overloaded environment. (J. Clin. Invest. 1990. 86:1255-1260.) Key words: inflammatory bowel disease - Crohn's disease • ulcerative colitis • epithelial cells $\bullet$ antigen presentation
\end{abstract}

\section{Introduction}

Since the studies of Perlmann and Broberger $(1,2)$ demonstrating the ability of peripheral white blood cells from patients with ulcerative colitis to kill epithelial cells from fetal gut cultures, attention has turned to an immunologic mechanism to explain the pathogenesis of inflammatory bowel disease. Twenty years later, significant progress has been made in terms of identifying the specific components of the mucosal immune

Address reprint requests to Dr. Lloyd Mayer, Mount Sinai Medical Center, Box 1089, 1 Gustave L. Levy Place, New York, NY 10029.

Received for publication 29 January 1990 and in revised form 1 May 1990

J. Clin. Invest.

(c) The American Society for Clinical Investigation, Inc.

$0021-9738 / 90 / 10 / 1255 / 06 \$ 2.00$

Volume 86, October 1990, 1255-1260 system present in the intestine (3-6) but little substantive data has been reported with regard to the presence and/or function of such cytotoxic cells in the gut (7-10). Indeed with the exception of one study by Shorter et al. (11), no differences have been detected in the number or functional cytotoxic $T$ cells between normal and inflammatory bowel disease (IBD) ${ }^{1}$ tissues $(12,13)$. Rather, most studies have suggested just the opposite, i.e., a lack of cytolytic T cells in IBD mucosa $(12,13)$. These negative findings, coupled with the inability to reproducibly isolate an infectious agent responsible for the pathogenesis of IBD (14-16), have raised new questions regarding the role of mucosal immunity in these diseases. Recently, several groups have turned their attention to the intestinal epithelial cell itself. Early studies in a rat model demonstrated that small bowel epithelial cells were capable of expressing class II antigens in a graft versus host reaction (17). These studies were subsequently extended to the human intestine where HLA-DR was detectable in tissue sections only on epithelial cells from patients with IBD and not from normal controls (18). Furthermore, the expression of class II antigens on intestinal epithelium appeared to relate to the presence of intraepithelial lymphocytes ( $T$ cells predominantly expressing the CD8 marker which may be cytotoxic in nature) (19). Using a more sensitive histochemical staining technique, we were able to demonstrate the presence of class II antigens on normal epithelial cells as well (20). Since the presence of such immunoregulatory molecules suggests that these cells may actually play a role in mucosal immunoregulation, we and others have recently investigated the possibility that class II antigen positive epithelial cells can function as normal antigen presenting cells. In both the human $(21)$ and rat $(22,23)$ normal epithelial cells are potent antigen-presenting cells (APCs) in antigen specific and nonspecific systems. Yet, unlike conventional accessory cells, epithelial cells appear to selectively stimulate suppressor T cells. Although the mechanism of suppressor cell induction is as yet unresolved, in this paper we demonstrate that in contrast to normal epithelial cells, epithelial cells from patients with both Crohn's and ulcerative colitis, but not other inflammatory diseases, fail to induce suppressor cells but rather stimulate potent antigen nonspecific $T$ helper/inducer cells. Failure to induce suppressor $\mathrm{T}$ cells in vivo may result in the chronic unrelenting inflammatory response seen in these diseases.

\section{Methods}

Cell isolation and culture. Heparinized venous blood was obtained from normal laboratory volunteers, diluted 1:3 with PBS and separated by Ficoll/Hypaque (Pharmacia Fine Chemicals, Piscataway, NJ)

1. Abbreviations used in this paper: $\mathrm{Ag}$, antigen; $\mathrm{APC}$, antigen presenting cell; $C D$, Crohn's disease; $C M$, culture medium; IBD, inflammatory bowel disease; IEL, intraepithelial lymphocytes; MLR, mixed lymphocyte reaction; UC, ulcerative colitis. 
density gradient centrifugation to obtain isolated mononuclear cells (MNC). Further separation to $\mathrm{T}$ and $\mathrm{B}$ cells was performed as previously described (24) using neuraminidase treated sheep red blood cell (sRBC) rosetting. Monocytes/dendritic cells were isolated by culturing varying numbers of non-T cells $\left(5 \times 10^{5}-5 \times 10^{3}\right)$ in triplicate microwell culture wells (Linbro Chemical Co. Hamden, CT) and allowing them to adhere during a 45-min incubation period in culture medium (CM) at $37^{\circ} \mathrm{C}$. Actual numbers of adherent cells were determined by subtracting the remaining nonadherent cells.

Cells were cultured in RPMI 1640 (Gibco Laboratories, Grand Island, NY), $5 \%$ agammaglobulinemic serum, $1 \%$ penicillin/streptomycin (Gibco Laboratories), and $2 \mathrm{mM}$ glutamine, henceforth termed CM.

Epithelial cells were isolated from freshly obtained surgical specimens; normal tissue was obtained from the distal margin of tissue resected from colonic or small bowel malignancies (at least $10 \mathrm{~cm}$ from the tumor), volvulus, familial polyposis, and chronic constipation. In IBD, epithelial cells were isolated from areas of active inflammation as well as grossly uninvolved margins (terminal ileum in ulcerative colitis (UC), resection margin in Crohn's disease [CD]). All specimens thus obtained were correlated with histologic analysis by the pathology department. Inflammatory controls included involved tissue from patients with diverticulitis $(n=8)$ (with and without local perforation), ischemic colitis $(n=3)$ and gold induced colitis $(n=1)$. Epithelial cells were isolated by a series of enzymatic steps as previously described (21). Purity and viability were improved by a series of density gradient centrifugation steps (Percoll; Sigma Chemical Co., St. Louis, MO; and Ficoll/Hypaque). The resultant epithelial cell preparation was $85-90 \%$ viable and $>95 \%$ pure $\left(<0.1 \mathrm{OKMI}^{+},<0.1 \mathrm{sIg}^{+}, 3-4 \% \mathrm{CD}^{+}[\mathrm{CD} 8]\right)$ and was utilized in the various assays of accessory cell function listed below. In some experiments, peripheral blood adherent cells were subjected to similar isolation steps to assure that the effects demonstrated did not relate to the isolation procedure used.

Mixed lymphocyte reaction. Isolated epithelial cells or adherent cells from each patient were irradiated $3,000 \mathrm{R}$ by a cesium irradiator and co-cultured in $\mathrm{CM}$ at varying cell concentrations with $1 \times 10^{5}$ allogeneic peripheral blood $\mathrm{T}$ cells. Such mixed lymphocyte reaction (MLR) cultures were maintained for $120 \mathrm{~h}$ at $37^{\circ} \mathrm{C}$ in a humidified 5\% $\mathrm{CO}_{2}$ incubator. During the last $18 \mathrm{~h}$ of culture $1 \mu \mathrm{Ci}\left[{ }^{3} \mathrm{H}\right]$ thymidine (Aquaeous methyl; sp act $1.9 \mathrm{mCi}$; ICN Pharmaceuticals, Inc., Irvine, CA) was added to each well. T cells alone or irradiated stimulator cells served as negative or background controls. Cells were harvested onto glass fiber filter mats and counted using a $\beta$ scintillation counter (Beckman 3801; Beckman Instruments Inc., Irvine, CA) as previously described (21). T cell stimulation was determined by the following formula: Stimulation index $=\mathrm{cpm} T \times$ stimulator/cpm $\mathrm{T}$ alone.

Immunofluorescence studies. Five million $\mathrm{T}$ cells were cultured alone or with equal numbers of irradiated allogeneic adherent cells or epithelial cells in $5 \mathrm{ml} \mathrm{CM}$ in a T25 flask as described above. After $48 \mathrm{~h}$ of culture, cells were harvested and T cells separated from stimulator cells by Ficoll-Hypaque density gradient centrifugation. In some experiments, further $T$ cell purification was achieved using SRBC rosetting as described above. T cells were then stained with various monoclonal antibodies by direct or indirect immunofluorescence techniques as previously described (25). Monoclonal antibodies used in this study were as follows: anti-CD3, anti-CD4, anti-CD8 (Coulter Electronics Inc., Hialeah, FL), 9.3 (recognizing $\mathrm{CD}^{+}$cytotoxic $\mathrm{T}$ cells kindly provided by Dr. Shu Man Fu, Oklahoma Medical Research Foundation, Oklahoma City, OK), anti-Tac (anti-low affinity IL2 receptor kindly provided by Dr. Tom Waldmann, National Cancer Institute, Bethesda, MD), OKT9 (transferrin receptor; Ortho Diagnostic Systems Inc., Raritan, NJ) and VG2 (anti-DR [21]). At least 5,000 cells were counted per analysis, gating for viable lymphocytes. Analysis was performed using an Epics $\mathrm{C}$ cytofluorograph (Coulter).

Isolation of $T$ cell subsets. T cells were cultured for $48 \mathrm{~h}$ and isolated as described above. Isolated $\mathrm{T}$ cells were aliquoted and subjected to further fractionation into $\mathrm{CD} 4$ and $\mathrm{CD}^{+} \mathrm{T}$ cell subpopulations as follows: $10-20 \times 10^{6} \mathrm{~T}$ cells were incubated with sterile un- conjugated anti-CD4 or CD8 antibody (1:4 dilution; Becton Dickinson \& Co., Sunnyvale, CA) for $30 \mathrm{~min}$ at $22^{\circ} \mathrm{C}$ with frequent shaking. After this initial incubation, cells were washed three times in PBS and resuspended in a $2 \%$ suspension of goat anti-mouse Ig-coated RBC as previously described (24). This suspension was pelleted at $1,000 \mathrm{rpm}$ for $5 \mathrm{~min}$ at $4^{\circ} \mathrm{C}$ and incubated a further $30 \mathrm{~min}$ on ice. After gently resuspending the pellet, the rosetted cells were isolated by Ficoll/Hypaque density gradient centrifugation. For $\mathrm{CD}^{+}$positive selection, $\mathrm{T}$ cells were $<2-6 \% \mathrm{CD}^{+}$. Interface cells $\left(\mathrm{CD}^{-}\right)$were $>90-96 \mathrm{CD}^{+}$ and $<2-6 \% \mathrm{CD}^{+}$. Similar purity was obtained for CD8 positive and negative selection. In general, negatively selected cells were used for studies of thymidine incorporation. Cells were resuspended at 1 $\times 10^{6} / \mathrm{ml}$ in $\mathrm{CM}$ and added alone to triplicate $100-\mu \mathrm{l}$ microwell cultures. After $72 \mathrm{~h}, 1 \mu \mathrm{Ci}{ }^{3} \mathrm{H}$ was added to these cultures for an additional 18-h period. Isolated but unfractionated $\mathrm{T}$ cells were used as controls in these assays to determine the effects of removal of the stimulator population. All results were compared to cultures where $T$ cells were left intact in $\mathrm{CM}$ alone or with irradiated stimulator cells. Stimulation was assessed as described above.

Assays of $T$ cell help and/or suppression of mitogen stimulation. Allogeneic control peripheral blood $\mathrm{T}$ cells were cultured in triplicate $100-\mu 1$ microwell cultures $\left(1 \times 10^{5}\right.$ cells/well $)$ in the presence or absence of PHA (1/100, Gibco Laboratories), Con A (10 $\mu \mathrm{g} / \mathrm{ml}$; Sigma Chemical Co.), or PWM (1/100, Gibco Laboratories). In order to determine whether MLR activated T blasts were functional helper or suppressor $\mathrm{T}$ cells, isolated T blasts (after $48 \mathrm{~h}$ of culture as described above) were added in varying concentrations to these cultures. In some experiments, these cells were irradiated $2,000 \mathrm{R}$ to inhibit their ability to proliferate in response to mitogen. Control cultures included $T$ blasts alone in the presence or absence of mitogen. The ability to help or suppress allogeneic $\mathrm{T}$ cell responses to a given mitogen was determined by the following formula: cpm $\mathrm{T}+$ mitogen $+\mathrm{T}$ blast/cpm $\mathrm{T}$ + mitogen $\times 100=\%$ help (positive No.) or suppression (negative No.)

Effect on MLR cultures. Similar studies were performed using MLR cultures. Isolated T blasts were added in varying cell concentrations to MLR cultures containing T cells stimulated with either the same stimulator population or a different allogeneic combination. This allowed for determination of the antigen specificity of the activated $\mathrm{T}$ cells.

Effect on $B$ cell differentiation. PBMC were cultured at $1 \times 10^{5}$ cells/well in $100-\mu$ l triplicate microwell cultures in the presence of PWM $(1 / 100)$. T blasts (irradiated and unirradiated) were added to these cultures at varying cell concentrations as described above. After 6 d, supernatants were harvested and assessed for total Ig secretion using ELISA (26). Positive controls were MNC cultured in the presence of PWM while the negative control was MNC in the absence of PWM. Degree of help or suppression was assessed as described above using Ig concentration rather than counts per minute.

\section{Results}

Epithelial cells from patients with IBD selectively stimulate $\mathrm{CD4}^{+} \mathrm{T}$ cells. MLR cultures were established using either irradiated epithelial cells or adherent cells from 42 patients with Crohn's disease, 38 with UC, 6 with diverticulitis, 2 with ischemic colitis, and 1 with gold-induced colitis, and 44 noninflammatory controls (margins of cancer specimens, sigmoid volvulus, familial polyposis, and chronic constipation). After $48 \mathrm{~h}$ of culture, T cells were isolated and analyzed by direct immunofluorescence for the CD4 and CD8 markers. As seen in Table I normal PB T cells stimulated with Crohn's or UC epithelial cells, like adherent cells, are predominantly of the CD4 phenotype.

In contrast, normal epithelial cells failed to stimulate a $\mathrm{CD4}^{+} \mathrm{T}$ cell response, but rather resulted in an increase of $\mathrm{CD}^{+} \mathrm{T}$ cells as previously reported (21). These studies were 
Table I. Epithelial Cells from IBD Selectively Stimulate CD4+ T Cells

\begin{tabular}{|c|c|c|c|}
\hline \multirow[b]{2}{*}{ Stimulator cells } & \multirow{2}{*}{$\begin{array}{l}\text { No. of } \\
\text { specimens }\end{array}$} & \multicolumn{2}{|c|}{$\begin{array}{c}\text { T cells } \\
\text { percent } \\
\text { immunofluorescence }\end{array}$} \\
\hline & & CD4 & CD8 \\
\hline & & \multicolumn{2}{|c|}{ $\pm S D$} \\
\hline 0 & 66 & $73 \pm 14$ & $24 \pm 7$ \\
\hline Non-T cells & 66 & $67 \pm 12$ & $28 \pm 10$ \\
\hline Normal epithelial cells & 44 & $12 \pm 16$ & $76 \pm 18$ \\
\hline Crohn's epithelium & 42 & $81 \pm 8$ & $10 \pm 6$ \\
\hline \multicolumn{4}{|l|}{ Ulcerative colitis } \\
\hline epithelium & 38 & $76 \pm 20$ & $20 \pm 12$ \\
\hline \multicolumn{4}{|l|}{ Inflammatory disease } \\
\hline epithelium & 12 & $15 \pm 7$ & $72 \pm 21$ \\
\hline
\end{tabular}

Normal peripheral blood $\mathrm{T}$ cells were co-cultured in the presence or absence of varying concentrations of irradiated $(3,000 \mathrm{R})$ stimulator cells. After 48-72 h of culture, activated $\mathrm{T}$ cells were isolated and stained with anti-CD4 and anti-CD8 mAbs. Staining was analysed by flow cytometry. Epithelium from Crohn's disease and ulcerative colitis are contrasted with conventional allogeneic stimulators (non-T cells) and normal and inflamed (diverticulitis, ischemic colitis, and gold-induced colitis) epithelium. There is a significant difference $(P<0.01)$ between $\mathrm{CD} 8+\mathrm{T}$ cells stimulated with normal epithelium and inflammatory controls compared with IBD epithelium.

reproducible in 42/42 CD and 35/38 UC specimens. Conversely, only one "normal" epithelial specimen stimulated $\mathrm{CD} 4^{+}$cells.

In order to determine whether the predominance of $\mathrm{CD}^{+}$ cells in the MLR culture containing IBD epithelium was due to the proximity of these cells to an active inflammatory process, epithelial cells were isolated from non-IBD inflammatory controls (diverticulitis, ischemic colitis, and gold-induced colitis). These cells were noted to express class II antigens at levels comparable to IBD epithelium by cytofluorographic analysis (data not shown). Like normal noninflamed epithelial cells, these cells selectively enhanced $\mathrm{CD}^{+} \mathrm{T}$ cells (Table I). Thus, it appears that the predominance of $\mathrm{CD} 4^{+} \mathrm{T}$ cells in MLR cultures does not relate to either the presence of underlying inflammation or the level of class II antigen $(\mathrm{Ag})$ expression.

This finding was corroborated when we looked at stimulation of $T$ cells by IBD epithelial cells from areas of inflammation as well as noninflamed areas. We have previously demonstrated that class II Ag expression by intestinal enterocytes is greater in CD even in noninflamed areas (20) where histologic analysis does not reveal active inflammation in the uninflamed margin. Using epithelial cells from these areas as well as ileal tissue from patients with UC (which is not reportedly involved in the disease process), we found that uninflamed epithelial cells from IBD specimens also failed to stimulate a $\mathrm{CD}^{+} \mathrm{T}$ cell response, but rather resulted in $\mathrm{CD} 4^{+} \mathrm{T}$ cell proliferation (Table II). These data suggest a more global process occurring at the level of the epithelial cell.

$C D 4^{+} T$ cells are actively proliferating in MLR cultures stimulated by IBD epithelium. Since the preponderance of $\mathrm{CD}^{+} \mathrm{T}$ cells in our cultures determined by staining does not necessarily translate into active proliferation of these cells, we
Table II. IBD Epithelium from both Involved and Uninvolved Areas Activate CD4+ T Cells

\begin{tabular}{cccc}
\hline & & \multicolumn{2}{c}{$\begin{array}{c}\text { T cells } \\
\text { percent }\end{array}$} \\
Stimulator cells & $\begin{array}{c}\text { No. of } \\
\text { specimens }\end{array}$ & CD4 & CD8 \\
\cline { 3 - 5 } $\begin{array}{c}\text { immunofluorescence } \\
\text { D }\end{array}$ & 66 & $73 \pm 14$ & $24 \pm 7$ \\
\hline $\begin{array}{c}\text { Crohn's epithelium } \\
\text { (involved) }\end{array}$ & 6 & $83 \pm 12$ & $13 \pm 4$ \\
$\begin{array}{c}\text { Crohn's epithelium } \\
\text { (uninvolved) }\end{array}$ & 6 & $78 \pm 17$ & $17 \pm 6$ \\
$\begin{array}{c}\text { Ulcerative colitis epithelium } \\
\text { (involved) }\end{array}$ & 7 & $78 \pm 15$ & $18 \pm 12$ \\
$\begin{array}{c}\text { Ulcerative colitis epithelium } \\
\text { (uninvolved) }\end{array}$ & 7 & $74 \pm 15$ & $22 \pm 10$ \\
\end{tabular}

Similar to experiments depicted in Table I, peripheral blood T cells were stimulated with isolated epithelial cells from grossly involved and uninvolved tissue. No significant difference was noted regardless of the tissue source.

isolated $\mathrm{CD}^{+}$and $\mathrm{CD}^{+} \mathrm{T}$ cells after $48 \mathrm{~h}$ of culture, and continued to culture them for an additional $72 \mathrm{~h}$, with the final $18 \mathrm{~h}$ in the presence of $\left[{ }^{3} \mathrm{H}\right]$ thymidine. In a representative experiment seen in Table III, $\mathrm{CD}^{+}$cells actively incorporated $\left[{ }^{3} \mathrm{H}\right]$ thymidine, whereas there was little, if any, proliferation of $\mathrm{CD}^{+} \mathrm{T}$ cells. This is in contrast to our previous findings using normal epithelial cells as stimulators $(21)$ where $\mathrm{CD}^{+} \mathrm{T}$ cells were the predominant cell type incorporating radiolabel.

Function of activated $C D 4^{+} T$ cell blasts in vitro. We have previously shown that $T$ cell blasts isolated from MLR cultures of $\mathrm{T}$ cells and normal epithelial cells function as potent $\mathrm{Ag}$ nonspecific suppressor $T$ cells. We performed similar studies using $T$ blasts from IBD epithelial cell-stimulated MLR cultures. CD epithelial cell-stimulated T blasts actively enhanced T cell responses to PHA (Fig. 1) and secondary MLR cultures (Fig. 2) in an antigen nonspecific fashion. In addition, these $T$ cell blasts provided potent help for Ig secretion when co-cultured with autologous or allogeneic B cells and PWM (Table IV). Similar findings were demonstrated when UC epithelial

Table III. Crohn's Epithelial Cells Induce the Proliferation of Helper T Cells in MLR

\begin{tabular}{lclc}
\hline Control cells & cpm & \multicolumn{1}{c}{ MLR cells } & cpm \\
\hline & $\pm S D$ & & $\pm S D$ \\
T cells & $343 \pm 98$ & T $\times$ epi & $23456 \pm 398$ \\
CD4+ T cells & $2455 \pm 234$ & CD4+ T $\times$ epi & $21998 \pm 241$ \\
CD8+ T cells & $221 \pm 78$ & CD8 + T $\times$ epi & $2034 \pm 79$
\end{tabular}

* $\mathrm{T}$ cells were cultured in CM alone for $48 \mathrm{~h}$ and isolated into Leu $2^{-}(\mathrm{CD4}+)$ or Leu $3^{-}(\mathrm{CD} 8+)$ subpopulations by an indirect rosetting technique. One hundred thousand cells were then recultured for an additional $72 \mathrm{~h}$ and pulsed with $[3 \mathrm{H}]$ thymidine for the final $18 \mathrm{~h}$ of culture.

$\ddagger \mathrm{T}$ cells were co-cultured with equal numbers of irradiated epithelial cells for $48 \mathrm{~h}$ and subsequently isolated into CD4 and CD8+ subpopulations and cultured as stated above. 


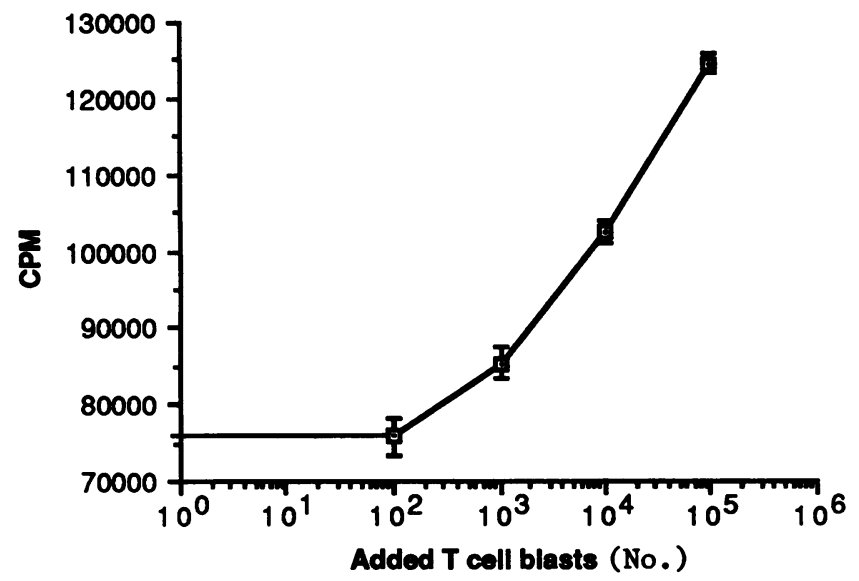

Figure 1. Normal peripheral blood T cells $\left(10^{5}\right)$ were cultured in the presence or absence of CD epithelium for $72 \mathrm{~h}$. T cell blasts were isolated (by Percoll density gradient) and recultured in varying concentrations in the presence of autologous $\mathrm{T}$ cells stimulated with PHA (1 $\mu \mathrm{g} / \mathrm{ml}$ ) for an additional $72 \mathrm{~h}$. The increase in thymidine incorporation was noted whether or not the $T$ cell blasts were irradiated. $T$ cell blasts co-cultured in the absence of PHA did not induce appreciable $T$ cell proliferation (not shown). Baseline proliferation for unirradiated $T$ blasts was $2,312 \pm 124$ and for resting $T$ cells, $414 \pm 53$. This experiment is representative of 12 experiments with Crohn's epithelium and 14 experiments with UC epithelium. Error bars represent standard deviations.

cell-stimulated $T$ cell blasts were co-cultured with $T$ cells and mitogen or allostimulators, although in general, the level of helper activity was less than that seen by CD-stimulated $T$ cells (data not shown). Moreover, Ag nonspecific $\mathrm{T}$ cell help was noted whether epithelial cells used for stimulation were isolated from involved or uninvolved areas (Table IV).

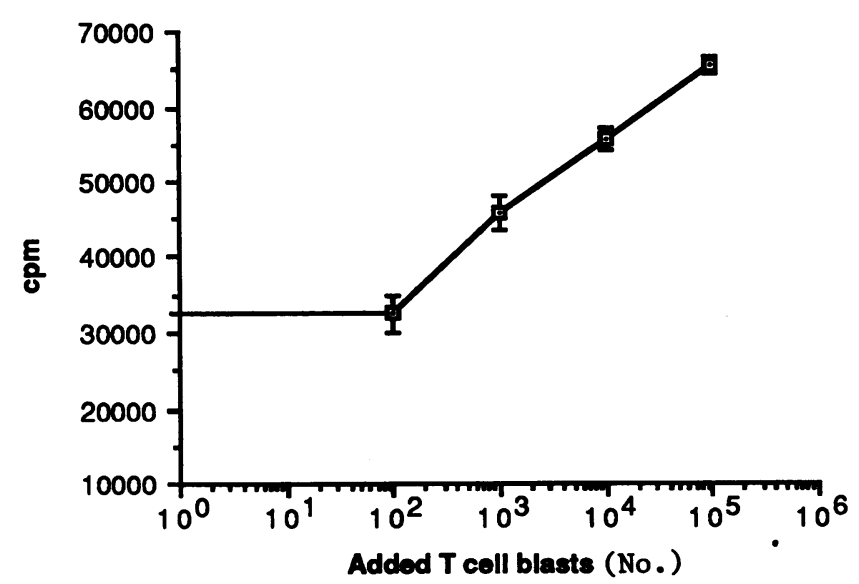

Figure 2. As in Fig. 1, normal peripheral blood T cells $\left(10^{5}\right)$ were cocultured with irradiated allogeneic stimulators $\left(10^{5}\right)$ for $120 \mathrm{~h}$ in the presence or absence of varying concentrations of $\mathrm{T}$ cell blasts derived from CD epithelial cell stimulated MLR cultures. As above, T cell blasts co-cultured in the absence of allogeneic stimulator cells did not induce appreciable $\mathrm{T}$ cell proliferation (not shown). Baseline proliferation for unirradiated $T$ blasts was $2,768 \pm 345$ and for resting $T$ cells, $189 \pm 24$. This experiment is representative of five experiments with Crohn's epithelium and three experiments with UC epithelium. Error bars represent standard deviations.
Table IV. T Cells Activated by CD Epithelial Cells Provide Potent Help for Immunoglobulin Secretion

\begin{tabular}{llrr}
\hline \multicolumn{1}{c}{ T cell source } & B cell source & PWM & \multicolumn{1}{c}{ IgG } \\
\hline & & & $n g / m l$ \\
- & Autologous & - & 1.3 \\
Peripheral blood & Autologous & + & 4.6 \\
CD epithelial cell (involved) & Autologous & + & 1234.8 \\
stimulated PB T & Autologous & + & 2165.6 \\
CD epithelial cell (uninvolved) & & & \\
stimulated PB T & Autologous & + & 1956.2 \\
\multicolumn{1}{c}{ - } & Allogeneic & - & 2.5 \\
Peripheral blood & Allogeneic & + & 3.2 \\
CD epithelial cell (involved) & Allogeneic & + & 887.9 \\
stimulated PB T & Allogeneic & + & 1487.1 \\
CD epithelial cell (uninvolved) & & & \\
stimulated PB T & Allogeneic & + & 1524.7 \\
& & & \\
\hline
\end{tabular}

T cells isolated from various MLR cultures were co-cultured with either autologous or allogeneic $B$ cells in the presence or absence of PWM $(1 \mu \mathrm{g} / \mathrm{ml})$ for $10 \mathrm{~d}$. Total Ig secretion was determined by ELISA. A marked increase in $T$ cell help was noted in those $T$ cells stimulated by IBD epithelium from either involved or uninvolved areas.

Epithelial cells from both small bowel and colon are comparable in their stimulation of specific $T$ cell subpopulations. One concern was that most of our initial control epithelial cell populations were isolated from colon and not small bowel. Since colonic epithelial cells express less class II $\mathrm{Ag}$ than small bowel epithelial cells, a trivial explanation for our findings could have been a difference in tissue sites, especially since the majority of $\mathrm{CD}$ specimens were from the ileum. Therefore, epithelial cells from normal ileal tissue from two patients undergoing a right hemicolectomy for a right-sided colon cancer, and ileum from a patient undergoing a subtotal colectomy for chronic constipation were contrasted with epithelial cells isolated from the colon of these same patients. As seen in Table $\mathrm{V}$, similar increases in $\mathrm{CD}^{+} \mathrm{T}$ cells were noted regardless of

Table V. Normal Epithelial Cells from both Small Bowel and Colon Activate CD8+ T Cells

\begin{tabular}{|c|c|c|c|}
\hline \multirow[b]{2}{*}{ Stimulator cells } & \multirow{2}{*}{$\begin{array}{c}\text { No. of } \\
\text { specimens }\end{array}$} & \multicolumn{2}{|c|}{$\begin{array}{c}\text { T cells percent } \\
\text { immunofluorescence }\end{array}$} \\
\hline & & CD4 & CD8 \\
\hline & & \multicolumn{2}{|c|}{ $\pm S D$} \\
\hline 0 & 66 & $73 \pm 14$ & $24 \pm 7$ \\
\hline Ileum (Normal) & 3 & $21 \pm 3$ & $74 \pm 15$ \\
\hline Colon (Normal) & 3 & $26 \pm 8$ & $68 \pm 7$ \\
\hline
\end{tabular}

As depicted in Table I, PB T cells were stimulated with either normal colonocytes or normal small bowel enterocytes from the same patient. Staining of $T$ cell blasts with anti-CD4 and -CD8 was performed after 48-72 h of culture. 
the source of epithelial cells. Given the findings already described (i.e., that uninvolved ileal epithelial cells from patients with UC still stimulate $\mathrm{CD}^{+}{ }^{+} \mathrm{T}$ cells), these data suggest that the source of epithelial cells is not the critical factor in the differences in stimulation of $\mathrm{T}$ cell subpopulations seen.

\section{Discussion}

Conventional class II Ag bearing APC (macrophages/dendritic cells) typically interact with immunocompetent $T$ cells resulting in the generation of predominantly helper $\mathrm{T}$ cell responses. Similar findings have been described for MLR cultures where the stimulus is response to foreign class II $\mathrm{Ag}$, although some proliferation of $\mathrm{Ag}$-specific suppressor and cytotoxic $\mathrm{T}$ cells have been reported $(27,28)$. We and others $(21,22)$ have recently described a novel role for the class II Ag-bearing intestinal enterocyte, that of an APC. However, in contrast to conventional APCs, normal epithelial cells appear to selectively induce the proliferation of $\mathrm{CD}^{+}$antigen nonspecific suppressor cells $(21,23)$. In this study we have looked at epithelial cells from patients with inflammatory bowel disease, a disorder which is thought to result from defects in immunoregulation. In contrast to normal epithelial cells, epithelial cells from patients with CD (42/42) or UC (35/38) selectively induce $\mathrm{CD}^{+} \mathrm{T}$ cell proliferation. These $\mathrm{CD} 4^{+} \mathrm{T}$ cells appear to be potent $\mathrm{Ag}$ nonspecific $\mathrm{T}$ helper cells as evidenced by their ability to augment $T$ cell mitogen responses, other primary and secondary MLR cultures, as well as provide help for Ig secretion by $B$ cells. It is unclear at present why $3 / 38$ UC patients' epithelial cells failed to stimulate a $\mathrm{CD}^{+} \mathrm{T}$ cell response. Since the majority of patients undergoing resection were on steroids and comparable medications at the time of surgery, one cannot attribute the failure of $\mathrm{CD}^{+} \mathrm{T}$ cell proliferation to medication. In addition, we were unable to detect any real differences in clinical course, age, extent, or severity of disease in these patients when compared to the rest of the group. In contrast, none of the epithelial cells isolated from $\mathrm{CD}$ patients stimulated $\mathrm{CD}^{+} \mathrm{T}$ cells, and in general, resulted in the proliferation of $\mathrm{T}$ helper cells. Furthermore, we were unable to explain the difference in $\mathrm{T}$ cell subpopulations stimulated by normal and IBD epithelial cells by the presence of underlying inflammation, since non-IBD inflammatory controls (i.e., ischemic colitis and diverticulitis) also stimulated $\mathrm{CD}^{+}$suppressor cells. In addition, this difference could not be ascribed to the source of the epithelium as normal small bowel-derived epithelium stimulated $\mathrm{CD8}^{+} \mathrm{T}$ cells in a comparable manner to colon-derived epithelium. Most importantly however, was the finding that epithelium from histologically uninflamed areas in IBD tissue also stimulated helper $T$ cells. These data suggest that there may be a defect in all epithelial cells in patients with IBD, i.e., a failure to normally activate suppressor $\mathrm{T}$ cells, which might keep local inflammation in check. Such a scenario makes inherent sense and helps to explain several previous findings in IBD. The increase in spontaneous secretion of IgG, reported by MacDermott et al. (29), may relate to the presence of activated $\mathrm{CD}^{+} \mathrm{T}$ cells. In addition, activated helper $T$ cells secrete lymphokines which may result in macrophage activation and secretion of a variety of nonspecific inflammatory mediators such as prostaglandins, superoxides, etc., which may be the final common pathway of tissue injury $(30,31)$.
The mechanism by which $\mathrm{CD}^{+} \mathrm{T}$ cells are activated by normal epithelial cells is not clear. Preliminary data (32) suggest that there may be a novel (non-class I) ligand for CD8 on normal epithelial cells. Cross-linking of CD8 on T cells by this ligand might conceivably activate these cells by stimulation of p56 $6^{\text {lck }}$, a sarc-like tyrosine kinase, in the intracytoplasmic tail of the CD8 molecule (33). Alternatively, a superantigen, selectively binding to and activating $C D 8^{+} \mathrm{T}$ cells, could be present bound to normal epithelial cells but absent in IBD epithelial cells. Studies to elucidate such possibilities are currently in progress.

Given our findings, there are still several questions remaining. One concern relates to the physiologic relevance of our findings. Numerous studies have reported CD4/CD8 ratios in the lamina propria, by both physical separation techniques and histochemical staining in situ, to be comparable to that seen in "normal" tissues $(13,34)$. Such studies may not be rigorous enough to detect subtle changes that may have profound physiologic implications. This is also true for intraepithelial lymphocytes (IEL). Again, no gross differences have been detected when comparing normal IELs with IELs from patients with $\operatorname{IBD}(34,35)$. However, in a situation where virtually all IELs are $\mathrm{CD}^{+}$, small changes in $\mathrm{CD}^{+} \mathrm{T}$ cell number and functional subpopulations might occur, which are not readily detectable by current methods. It is possible that such changes might be associated with alterations in immune regulation of the gastrointestinal tract. We await more carefully performed morphometric analyses to fully explore such a possibility. Another concern is the difficulty in explaining why, if the epithelial cell defect is global in IBD, only selected areas of the bowel are involved in $\mathrm{CD}$, and more puzzling, why the small bowel is never involved in UC. Of interest is the observation that there is a much higher incidence of "pouchitis" (idiopathic inflammation of the surgically produced pouch) in UC patients after formation of an ileal pouch, compared with patients who opt for pouches for noninflammatory disease (i.e., familial polyposis). This suggests that the substrate (i.e., abnormal epithelial cells) is present, but additional as yet unidentified factors are required (i.e., as the pouch becomes more "colon-like") to express clinical disease.

Lastly, it must be remembered that our studies have been performed with specimens obtained at surgery. This could potentially bias our results since patients who require surgery may be a distinct subset of IBD patients, i.e., with medically intractable and longstanding disease. We have been unable to obtain sufficient numbers of epithelial cells from biopsy specimens and epithelial cell lines are not available from either normal bowel or inflammatory bowel disease patients. Despite these concerns, we feel that our findings can be more globally extrapolated given the fact that $\mathrm{CD}^{+} \mathrm{T}$ cell stimulation is seen with epithelial cells from both uninvolved and involved tissues.

Therefore, taken together, our data suggest a novel potential pathogenetic mechanism for the development of IBD: that of an intrinsic defect in epithelial cells which results in the failure to stimulate a normal suppressor $T$ cell response. In this setting one need not invoke one specific antigen, bacteria, or virus to explain the disease process, but rather any insult in a genetically predisposed host, coupled with an increase in antigenic load caused by erosion of the mucosa, could result in the chronic unrelenting and uncontrolled inflammation that is IBD. 


\section{Acknowledgments}

The authors wish to thank Drs. Arthur Aufses, Irwin Gelernt, Barry Salky, Adrian Greenstein, Isadore Kreel, and Joel Bauer for their help in obtaining surgical specimens. We would also like to thank Ms. Debbie Matz for her assistance in the preparation of this manuscript.

This study was supported by U. S. Public Health Service grants AI-23504, AI-24671, and CA-41583; a grant from the Burrill B. Crohn Foundation; and the National Foundation for Ileitis and Colitis. Dr. Mayer is a recipient of an Irma T. Hirschl Career Trust Award.

\section{References}

1. Broberger, O., and P. Perlmann. 1963. In vitro studies of ulcerative colitis. I. Reactions of patient's serum with human fetal colon cells in tissue cultures. J. Exp. Med. 117:705-715.

2. Perlmann, P., and O. Broberger. 1963. In vitro studies of ulcerative colitis. II. Cytotoxic action of white blood cells from patients on human fetal colon cells. J. Exp. Med. 117:717-733.

3. Wolf, J. L., and W. A. Bye. 1984. The membranous epithelial (M) cell and the mucosal immune system. Annu. Rev. Med. 35:95112.

4. Mestecky, J., J. R. McGhee, and C. O. Elson. 1988. Intestinal IgA system. Immunol. Allergy Clin. N. Am. 8:349-368.

5. James, S. P., M. Zeitz, M. Kanof, and W. C. Kwan. 1988. Intestinal lymphocyte populations and mechanisms of cell-mediated immunity. Immunol. Allergy Clin. N. Am. 8:369-391.

6. Targan, S. R., M. F. Kagnoff, M. D. Brogan, and F. Shanahan 1987. Immunologic mechanisms in intestinal diseases. Ann. Intern. Med. 106:853-870.

7. MacDermott, R. P., G. O. Franklin, K. M. Jenkins, I. J. Kodner, G. S. Nash, and I. J. Weinreib. 1980. Human intestinal mononuclear cells. I. Investigation of antibody-dependent, lectin-induced, and spontaneous cell-mediated cytotoxic capabilities. Gastroenterology. 78:4756.

8. Falchuk, Z. M., E. Barnhard, and I. Machado. 1981. Human colonic mononuclear cells: studies on cytotoxic function. Gut. 22:290-294.

9. Chiba, M., W. Bartrik, S. G. Remine, W. R. Thayer, and R. G. Shorter. 1981. Human colonic intraepithelial and lamina propria lymphocytes: cytotoxicity in vitro and the potential effects of the isolation method on their functional properties. Gut. 22:177-186.

10. Targan, S., L. Britvan, R. Kendall, S. Vimadalal, and A. Soll 1983. Isolation of spontaneous and interferon inducible natural killer cells from human colonic mucosa: lysis of lymphoid and autlogous epithelial target cells. Clin. Exp. Immunol. 54:14-22.

11. Shorter, R. G., D. B. McGill, and R. C. Bahn. 1984. Cytotoxicity of mononuclear cells for autologous colonic epithelial cells in colonic diseases. Gastroenterology. 86:13-22.

12. MacDermott, R. P., M. J. Bragdon, I. J. Kodner, and M. Bertovich. 1986. Deficient cell-mediated cytotoxicity and hyporesponsiveness to interferon and mitogenic lectin activation by inflammatory bowel disease peripheral blood and intestinal mononuclear cells. Gastroenterology. 90:6-11.

13. Fiocchi, C., R. R. Tubbs, and K. Youngman. 1985. Human intestinal mononuclear cells exhibit lymphokine-activated killer cell activity. Gastroenterology. 88:625-637.

14. Phillpotts, R. J., J. Herman-Taylor, and B. N. Brooke. 1979. Virus isolation studies in Crohn's disease: a negative report. Gut. 20:1057-1062.

15. Kobayashi, K., M. J. Blaser, and W. R. Brown. 1988. Immunohistochemical evidence of lack of association of mycobacteria and Crohn's disease. Gastroenterology. 94:232a. (Abstr.)

16. Taylor-Robinson, D., C. A. O'Morain, B. J. Thomas, and A. J.
Levi. 1979. Low frequency of chlamydial antibodies in patients with Crohn's disease and ulcerative colitis. Lancet. i:1162-1163.

17. Mason, D. W., M. Dallman, and A. N. Barclay. 1981. Graft versus host disease induces expression of Ia antigen in rat epidermal cells and gut epithelium. Nature (Lond.). 293:150-151.

18. Selby, W. S., G. Janossy, D. Y. Mason, and D. P. Jewell. 1983. Expression of HLA-DR antigens by colonic epithelium in inflammatory bowel disease. Clin. Exp. Immunol. 53:614-621.

19. Cerf-Bensussan, N., A. Quaroni, J. T. Kurnick, and A. K. Bhan. 1984. Intraepithelial lymphocytes modulate Ia expression by intestinal epithelial cells. J. Immunol. 132:2244-2252.

20. Mayer, L., D. Eisenhardt, P. Salomon, W. Bauer, R. Plous, and L. Piccininni. 1990. Expression of class II molecules on intestinal epithelial cells in man: differences between normal and inflammatory bowel disease. Gastroenterology. In press.

21. Mayer, L., and R. Shlien. 1987. Evidence for function of Ia molecules on gut epithelial cells in man. J. Exp. Med. 166:1471-1483.

22. Bland, P. W., and L. G. Warren. 1986. Antigen presentation by epithelial cells of the rat small intestine. I. Kinetics, antigen specificity and blocking by anti-Ia antisera. Immunology. 58:1-7.

23. Bland, P. W., and L. G. Warren. 1986. Antigen presentation by epithelial cells of the rat small intestine. II. Selective induction of suppressor T cells. Immunology. 58:9-14.

24. Mayer, L., S. M. Fu, and H. G. Kunkel. 1982. Human T cell hybridomas secreting factors for IgA specific help, polyclonal B cells activation and B cell proliferation. J. Exp. Med. 156:1860-1865.

25. Mayer, L., S. M. Fu, C. Cunningham-Rundles, and H. G. Kunkel. 1984. Polyclonal immunoglobulin secretion in patients with common variable immunodeficiency using monoclonal B cell differentiation factors. J. Clin. Invest. 74:2115-2120.

26. Mayer, L., S. P. Kwan, C. Thompson, H. S. Ko, N. Chiorazzi, T. Waldmann, and F. Rosen. 1986. Evidence for a defect in "switch" T cells in patients with immunodeficiency and hyper-immunoglobulinemia M. N. Engl. J. Med. 314:409-413.

27. Damle, N. K., and E. G. Engleman. 1983. Immunoregulatory T cell circuits in man. Alloantigen-primed inducer $\mathrm{T}$ cells activate alloantigen-specific suppressor $T$ cells in the absence of the initial antigenic signal. J. Exp. Med. 158:159-173.

28. Vande Stouwe, R. A., H. G. Kunkel, J. P. Halper, and M. E. Wexler. 1977. Autologous mixed lymphocyte culture reactions and generation of cytotoxic cells. J. Exp. Med. 146:1809-1814.

29. Scott, M. G., M. H. Nahm, K. Macke, G. S. Nash, M. J. Bertovich, and R. P. MacDermott. 1986. Spontaneous secretion of IgG subclasses by intestinal mononuclear cells: differences between ulcerative colitis, Crohn's disease, and controls. Clin. Exp. Immunol. 66:209-215.

30. Sharon, P., and W. F. Stenson. 1984. Enhanced spontaneous secretion of leukotriene B4 by colonic mucaosa in inflammatory bowel disease. Gastroenterology. 86:453-460.

31. Donowitz, M. 1985. Arachadonic acid metabolites and their role in inflammatory bowel disease: an update requiring addition of a pathway. Gastroenterology. 88:580-587.

32. Mayer, L., D. Eisenhardt, and W. Bauer. 1988. Mechanism of induction of $\mathrm{CD}^{+} \mathrm{T}$ cells by normal intestinal epithelium. Gastroenterology. 94:293a. (Abstr.)

33. Veillette, A., M. Bookman, E. Horak, L. Samelson, and J. Bolen. 1988. Signal transduction through the CD4 receptor involves the activation of the internal membrane tyrosine-protein kinase $\mathrm{p} 56^{\text {lck }}$. Nature (Lond.). 338:257-259.

34. Hirata, I., G. Berrebi, L. L. Austin, D. F. Keren, and W. O. Dobbins. 1986. Immunohistological characterization of intraepithelial and lamina proprial lymphocytes in control ileum and colon and in inflammatory bowel disease. Dig. Dis. Sci. 31:593-603.

35. Geboes, K., P. Rutgeerts, F. Penninckx, V. Desmet, and G. Vantrappen. 1988. Changes in small intestinal epithelial expression of MHC class II antigen after terminal ileal resection for Crohn's disease. Int. J. Colorectal Dis. 3:102-108. 